\title{
Morphological and ecological-biological evaluation of the decorative species of the genus Lupinus $L$.
}

\author{
H.V. Pantsyreva \\ Vinnytsia National Agrarian University, Vinnytsia, Soniaczna St. 3., Ukraine. \\ E-mail: apantsyreva@ukr.net
}

Received: 21.08.2019. Accepted: 21.09.2019

\begin{abstract}
The article describes the characteristics of decorative species of the genus Lupinus $L$. in the course of introductory studies on the basis of experienced exhibition areas of the Botanical Garden «Podillya» of the Vinnytsia National Agrarian University. An analysis of the species composition of the genus Lupinus $L$. has been carried out and the prospects of their use for landscaping of various objects of the Podillya area have been determined. In order to differentiate plants in accordance with the scope of their possible use, the morphometric indices of the most promising representatives of this genus are given. It has been established that all investigated species are of interest as potentially valuable objects for enrichment of assortment of domestic ornamental plants. It is established that natural possibilities of representatives of the genus Lupinus L., plasticity to change their life form, high quality by the aggregate of characteristics that determine their decorative character, characterizes the investigated plants as a source for introducing and enriching the range of decorative cultures in Ukraine. Thus, the introduction of representatives of the genus Lupinus $L$. will enable to significantly expand the range of ornamental plants and enrich the cultivated flora of the Podillya region and Ukraine as a whole.
\end{abstract}

Keywords: Lupinus L.; introduction; morphology; phenology; ecological and biological properties; biomorphological features

\section{Introduction}

Introduction to the wide industrial practice of new promising species and forms of plants, selected as a result of many years of introductory research, is one of the main goals of ecology science. The number of species, forms, varieties of introduced plants of the genus Lupinus (Fabaceae), which are common in Ukraine, is limited. Some of them are the property of only introductory centers and are rarely used in landscaping because of the lack of data on biological characteristics and effective methods for their reproduction in culture (Mazur et al., 2018). For Ukraine, the urgency of these issues is compounded by the fact that the range of decorative crops used in our country is still poor. Introduction of representatives of the genus Lupinus for gardening will allow to significantly expand the range of ornamental plants and enrich the cultivated flora of Ukraine (Bessonova, 2010). Given the variety of decorative species of the Lupinus genus by purpose, colored a gamut, a habit, a form of decorative elements, and a as well as their significant amount in the culture of developed countries of the world, taking into account the fact of their insignificant number in this areas of our state, the question of determining the possibilities and ways of using the potential of these plants for the enrichment of the cultiogenic fraction of flora is important as with scientific, and practical points of view (Bruks, 2009; Mazur et al., 2019). His decision will become an essential step in improving the quality of the domestic assortment of ornamental plants (Laptiev, 2001). In this connection, the purpose of the work was to study the biological characteristics of the decorative species of the genus Lupinus L. (Mazur et al., 2017).

\section{Material and Methods}

The purpose of the study was to: describe the natural habitats of the representatives of the genus Lupinus; to study morphological features with the study of ontogenesis and phenology of hybrids and varieties; present an assessment of environmental and biological properties; to determine the perspectives of the use of culture and potential for introduction of investigated varieties, hybrids (Talibov et al., 2008). The research was conducted during 2016-2018 on the basis of the exhibition area of the Podillya Botanical Garden of the Vinnytsia National Agrarian University. The soil-climatic conditions of the studied area are favorable for the cultivation of the studied species of the genus Lupinus $L$. The initial introduction assessment of the studied flower and decorative species was carried out using conventional methods in ornamental horticulture and the method of state variety testing. The varieties/hybrids L. polyphyllus Lindl were studied. Lulu-Russell, Minaret and $L$. perennis L. - Albus, Fireworks of Foreign Selection (Mazur et al., 2019). Analyzing the state register of varieties of decorative species of the genus Lupinus L. not found (Kataloh sortiv roslyn, 2018).

\section{Results}

Of the many species of the genus Lupinus (according to the classification of different authors from several dozens to several hundred), in most countries of the world, including Ukraine, only four cultivate: L. angustifolius L., L. luteus L., L. albus L., L. mutabilis L. The created small-alkaloid forms of perennial L. polyphyllus Lindl. Are in demand, but the seed fund has not yet been created. On the basis of this species, many varieties (mainly overseas selection) have been obtained, which are used as crops (Ogorodnikov et al., 1993; Pantsyreva, 2016; Rusanov, 1950).

The question of studying the morphological and ecological and biological characteristics of the representatives of the genus Lupinus devoted to the study of many scientists Kaminsky V.F., Petrichenko V.F., Golodna A.V., Pantsyreva H.V. and etc. 
After analyzing the works of domestic and world scientists, the natural habitats of the representatives of the genus Lupinus are described (see Table 1).

Table 1. The natural habitat of the genus Lupinus performance and minimum temperature.

\begin{tabular}{|c|c|c|}
\hline Species & Natural habitat & Minimum temperatures, ${ }^{\circ} \mathrm{C}$ \\
\hline L. Polyphyllus Lindl. & West Australia & $-6,7-10,8$ \\
\hline L. pilosus & Greece, Turkey, Lebanon, Syria, Israel, West Jordan & $-7,8-12,5$ \\
\hline L. athlanticus & Australia & $-6,6-16,8$ \\
\hline L. digitatus & Egypt & $-1,3-5,7$ \\
\hline L. hispanicus & Northwest Spain, Northern Portugal & $-12,9-17,6$ \\
\hline L. princei & the mountains of Kenya and Tanzania, Southern Ethiopia & $-12,7-19,8$ \\
\hline L. albicaulis Douglas & Canada & $-4,9-12,2$ \\
\hline L. ornatus Douglas & Peru & $-7,0-12,2$ \\
\hline L. arboreus Sims. & USA, Canada, Ireland, United Kingdom, Zeland & $-3,9-12,3$ \\
\hline L. perennis L. & USA, Canada & $-5,7-12,3$ \\
\hline L. nootkatensis Donn ex Sims. & Canada, Scotland, Norway, Sweden, Kamchatka & $-5,6-30,9$ \\
\hline
\end{tabular}

According to literary sources, all species of lupine on this continent were imported by the first settlers from America. At the end of the last century, new species with the decorative qualities of L. cosentinii, L. athlanticus were created along with the traditional lupine species (narrow, white, yellow) in Australia. and L. pilosus, which have become an integral part of Australian scientific research. Having analyzed literary data, in addition to those listed, on the opinion of the Australian scholars, for introduction in culture is perspective still decorative species - $L$. prince, $L$. digitatus and L. hispanicus. With a small experience in growing ornamental plants of this genus, the vast majority of them in the conditions of European countries, as well as the USA and Canada can develop well, tolerate the cold season, blossom and fruiting. However, the question of the characterization of the aforementioned species is still insufficiently studied (Chichev, 1981; Mazur et al., 2018; Sowling, 1994). It was found that in the conditions of Podillya the study of the species of lupine in the form of life - herbaceous polycarpus, geophytes, for ecomorphous heliophytes, but easily manifested as heliocephytes, for hydromorphous - mesophytes, under the phenorhytmotype belong to the group of summer-autumn-green plants (Table 2).

Table 2. Biomorphological features of decorative species of the genus Lupinus $L$.

\begin{tabular}{|c|c|c|c|c|c|}
\hline \multirow{2}{*}{ Variety / hybrid } & \multirow{2}{*}{ Life form } & \multirow{2}{*}{ Type of vegetation } & \multicolumn{2}{|c|}{ Sizes of plants, sm } & \multirow{2}{*}{ Duration of flowering, days } \\
\hline & & & height & width & \\
\hline \multicolumn{6}{|c|}{ L. polyphyllus Lindl. } \\
\hline Lulu-rassel & & Summer Green & 50 & $20-25$ & 40 \\
\hline Minaret & Perennials & Summer-Autumn-Green & 50 & $30-35$ & 45 \\
\hline \multicolumn{6}{|c|}{ L. perennis L. } \\
\hline Albus & & & 120 & $40-50$ & 55 \\
\hline Feerverk & Perennials & Summer-Autumn-Green & 150 & $50-60$ & 60 \\
\hline
\end{tabular}

It was investigated that plant decoration in new conditions depends on their ability to reproduce their characteristic features, which is manifested in the external state of plants and in the nature of the passage of the main phenophases (Markovskyi, 2002; Pantsyreva, 2016). Biometric indices of the studied type of lupine of multidrug, which made it possible to determine the level of decorative varieties and flower productivity, were investigated to determine the correspondence of plant parameters to their varietal characteristics in Podillya conditions (Sydoruk, 2007). The main morphometric parameters of plants depended on many factors: weather-climatic conditions of the year, varietal characteristics of plants, vegetation period (Horobets, 2017; Vdovenko, 2018). By studying the flowering phase, his dynamics with regard to the duration of flowering, which is presented in the consolidated diagram (Figure 1 and Figure 2) was studied in detail.

Figure 1. Dynamics of the flowering time of varieties and hybrids of decorative species of the genus Lupinus L., days.

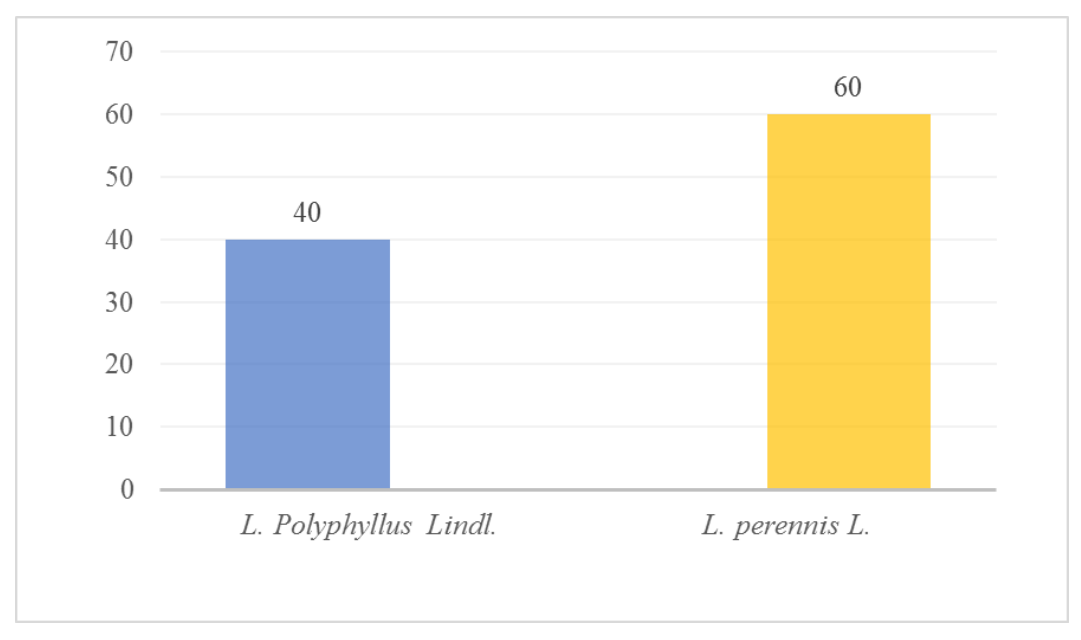


The highest rates of flowering time were recorded in L. perennis L. (60 days Feerverk). Somewhat lower rates were observed in L. polyphyllus Lindl. (hybrid - Lulu-rassel - 40 days). From the practical point of view, all investigated species are of interest as potentially valuable objects for enriching the range of ornamental plants in Ukraine and are promising for improving the condition of parks, gardens, gardens in the Podillya area (Pantsyreva, 2017). It is the enrichment of the variety of decorative crops introduced by the species of the Lupine genus, the expansion of variants of simple and complex garden compositions with their participation, more even distribution within the settlements, will significantly approximate the design of the inhabited cities of Ukraine to the level of the best world standards (Vdovenko et al., 2018). By studying the biomorphological features of the decorative species of the genus Lupinus L., as well as in establishing requirements for the decorative qualities of a variety or hybrid, the value of the assessment and selection of plants according to economic and biological indicators - the ability to reproduce, the productivity of flowering, resistance to illness and to unfavorable conditions - is greatly increased (Pantsyreva, 2018).

Figure 2. General view of flowering varieties and hybrids of ornamental species of the genus Lupinus L. exposition area at Vinnytsia National Agrarian University.

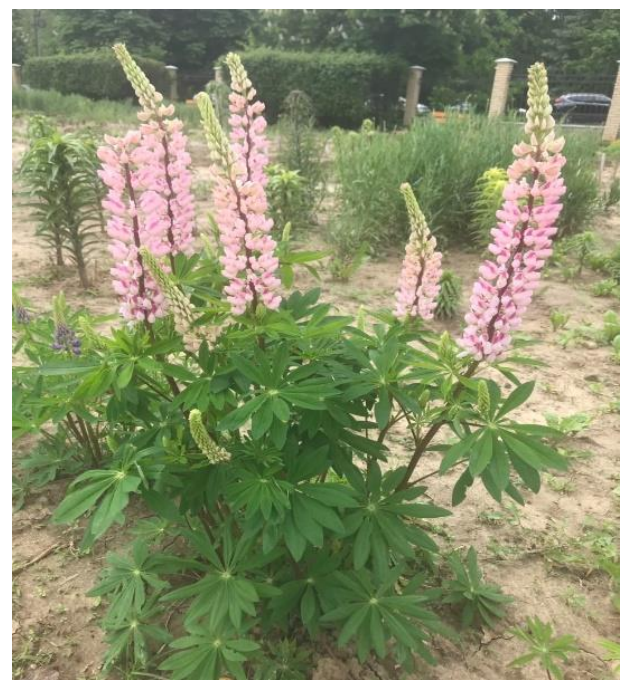

L. Polyphyllus Lindl. (Lulu-rassel)

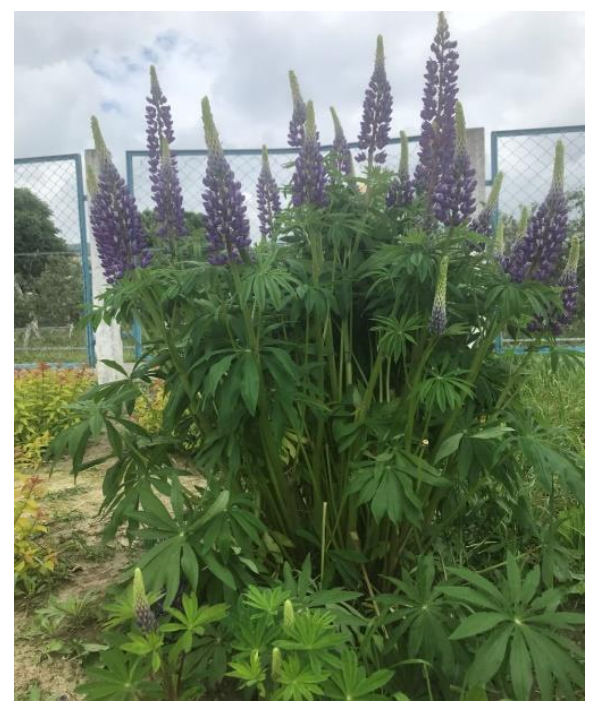

L. perennis L. (Feerverk)

To determine the suitability of the plants we examined for their use in landscaping, we carried out their assessment on the complex of economic-biological indicators with the inclusion of individual economically significant elements from the system of criteria foreseen for the assessment of decorative (Table 3).

Table 3. Estimation of decorative value of ornamental species of genus Lupinus $L$.

Title of the sign Transfer coefficients

\section{Lulu-rassel}

5 - ball

5

to burning

The size of the flower

Inflorescence (size, density of flower placement, number of flowers)

The quality of the peduncle

Bush (shape, strength, decorative)

Repairs

The clarity of flowering

Originality

Condition of plants (equality of variety) Total
4

1

4

2

2

2

2

2

1
100 - ball

20

5

16

10

10

8

8

8

90
Feerverk

5 - ball

100 - ball

5

20

5

5

5

20

5

10

5

10

8

10

10

5

98

According to the results of the research, varieties and hybrids of the decorative species of the genus Lupinus L. well adapted to the conditions of cultivation, were practically not affected by illnesses and were sufficiently resistant to adverse factors. And as the results of the introduction of varietal estimates, according to their decorative and economic and biological qualities deserve a positive assessment.

\section{Conclusion}

All species of the genus Lupinus, which have undergone the initial introductory test by a set of indicators that determine their decorative and economic and biological qualities, are assessed as well adapted to the edaphic climatic conditions of Podillya and are recommended as objects for enriching the plant variety for the landscaping of collection and exhibition funds.

\section{References}

Bessonova, V.P. (2010). Roslyny kvitnykiv. Dovidnyk, Dnipropetrovsk: Svidler. 
Bruks, D.z.h. (2009). Short entsyklopedyia sadovoho dyzaina. ZAO, BMM.

Chichev, A.V. (1981). ynanthropic flora of the city of Pushchino. Ying: Ecology of a small town [The synanthropic flora of the city of Pushchino. In: Ecology of the small town]. NTSBI, Pushchino, 18-42.

Horobets, V.F. (2017). A collection of viticultural breweries from vikoristanni by the method of distant hibridization. Factors of experimental evolution of organisms, 2, 128-132.

Catalon sorti roslin, commonplace for broader in Ukraine on 2018 rik (vytiah), (2018), 412-414.

Plant Collections of the Botanical Garden of SFedU: catalog of plants that have passed the introduction test (2014). Izdatel'stvo SFedU, Rostovon-Don.

Laptiev, O.O. (2001). Introduction and acclimatization of roslins with the basics of landscaping. Kiev, Phytosociocenter.

Markovskyi, Yu. (2002). Dekoratyvnue mnoholetnyky. SPb., Myr y semia,.

Mazur, V.A., Prokopchuk, V.M., Pantsyreva, H.V. (2018). Primary introduction assessment of decorative species of the lupinus generation in Podillya. Scientific Bulletin of UNFU, 28(7), 40-43.

Mazur, V.A., Pantsyreva, H.V., Mazur, K.V., Monarkh, V.V. (2019). Ecological and biological evaluation of varietal resources Paeonia L. in Ukraine. Acta Biologica Sibirica, 5 (1), 141-146.

Mazur, V.A., Didur, I.M., Pantsyreva, H.V., \& Telekalo, N.V. (2018). Energy-economic efficiency of grain-crop cultures in the conditions of the right-bank Forest-Steppe of Ukraine. Ukrainian J Ecol, 8(4), 26-33.

Mazur, V.A., \& Pantsyreva, H.V. (2017).

Vplyv tekhnolohichnykh pryiomiv vyroshchuvannia na urozhainist i yakist zerna liupynu Biloho v umovakh Pravoberezhnoho Lisostepu. Silesian economy and deprivation. Vinnytsia, VNAU, 7(1), 27-36.

Mazur, V.A., Pantsyreva, H.V., Mazur, K.V. \& Didur, I.M., (2019). Influence of the assimilation apparatus and productivity of white lupine plants. Agronomy research. 17(1), 206-219.

Ogorodnikov, A.Ya. (1993). Method of visual assessment of bioecological properties of woody plants in populated areas of the steppe zone. In: Introduction of plants. Izdatel'stvo Rostovskogo universiteta, Rostov-on-Don, 50-58.

Pantsyreva, H.V. (2016). Vplyv elementiv tekhnolohii vyroshchuvannia na indyvidualnu produktyvnist roslyn liupynu Biloho. Visnyk DDAEU, Organic Ecology. Dnipro, Ahronomichni nauky, 2.

Pantsyreva, H.V. (2016). Doslidennya varietal resources in the former lupine (Lupinus albus L.) v Ukrayini. Vinnycya, 4, 88-93.

Pantsyreva, H.V. (2017). Formulated by grain productivity, lupine bilono is a fallow species of technolonical preying in the minds of the rightbank forest-steppe. Dys. na zd. nauk. st. k. s.-h. n. Kam'ianets-Podilskyi, 100-101.

Pantsyreva, H.V. (2018). Research of sortal resources of grape species of Paeonia L. in Ukraine. Scientific Bulletin of UNFU, 28(8), 74-78.

Rusanov,F.N. (1950). New methods of plant introduction. Bull. Main Botanical Garden of the Academy of Sciences of USSR, Moscow, 7, 2736.

Sowling, W.A. (1994). Plant breeding for stable agriculture: Presidential Address. Western Australia, 183-184.

Sydoruk, T.M. (2007). Travianysti bahatorichni roslyny vidkrytoho gruntu Natsionalnoho dendroparku Sofiivka. Uman: UVPP, 115-122.

Talibov, T.H., Ibrahimov, A.Sh. (2008). Taxonomic spectre of the flora of Nakhchivan Autonomous Republic. Nakhchivan: Ajamy.

Vdovenko, S.A., Prokopchuk, V.M., Palamarchuk, I.I., \& Pantsyreva, H.V. (2018). Effectiveness of the application of soil milling in the growing of the squash (Cucurbita pepo var. giraumontia) in the right-benk forest stepp of Ukraine. Ukrainian J Ecol, 8(4), 1-5.

Vdovenko, S.A., Pantsyreva, G.V., Palamarchuk, I.I., \& Lytvyniuk, H.V. (2018). Symbiotic potential of snap beans (Phaseolus vulgaris L.) depending on biological products in agrocoenosis of the right-bank forest-steppe of Ukraine. Ukrainian J Ecol, 8(3), 270-274.

Citation: Pantsyreva, H.V. (2019). Morphological and ecological-biological evaluation of the decorative species of the genus Lupinus L.. Ukrainian Journal of Ecology, 9(3), 74-77.

(cc) Br This work is licensed under a Creative Commons Attribution 4.0. License 